\title{
Transfer of Bacteroides clostridiiformis subsp. clostridiiformis (Burri and Ankersmit) Holdeman and Moore and Bacteroides clostridiiformis subsp. girans (Prévot) Holdeman and Moore to the Genus Clostridium as Clostridium clostridiiforme (Burri and Ankersmit) comb. nov.: Emendation of Description and Designation of Neotype Strain
}

\author{
ELIZABETH P. CATO AND CAROLYN W. SALMON \\ Anaerobe Laboratory, Virginia Polytechnic Institute and State University, Blacksburg, Virginia 24061
}

\begin{abstract}
Twenty-five strains of bacteria with characteristics that conform to those given in the original and subsequent descriptions of the organism currently known as Bacteroides clostridiiformis (Burri and Ankersmit) Holdeman and Moore have been found to produce heat-resistant spores, which are often difficult to detect. Motility, also difficult to demonstrate in these strains, was found to be a variable characteristic within strains. We propose that $B$. clostridiiformis subsp. clostridiiformis (Burri and Ankersmit) Holdeman and Moore and $B$. clostridiiformis subsp. girans (Prévot) Holdeman and Moore be transferred to Clostridium as Clostridium clostridiiforme (Burri and Ankersmit) comb. nov. Prévot's strain 171 I ( = ATCC 29084 = VPI 3303), placed by Prévot in Ristella clostridiiformis, is designated as the neotype strain. Previously undescribed characteristics of this species are presented.
\end{abstract}

In 1906, Ankersmit (1) described an organism isolated in the laboratory of R. Burri, Zurich, from a bovine intestinal tract and named it Bacterium clostridiiforme. It was described as an obligately anaerobic, gram-negative rod, 2.0 to $3.0 \mu \mathrm{m}$ long by $0.75 \mu \mathrm{m}$ wide, spindle shaped, with sharply pointed ends. Cells were usually in pairs, although sometimes they occurred in short chains. Although the cells morphologically resembled small clostridia, even with occasional swellings, spores were not observed, and the cells did not survive heating for $15 \mathrm{~min}$ at $80 \mathrm{C}$. Surface colonies on glucose agar were 1.0 to $1.5 \mathrm{~mm}$ in diameter, circular, entire, grayish, and somewhat translucent with a soft consistency and a crystalline appearance. Colonies in glucose agar deeps were lenticular and semiopaque with a smooth edge. After 2 days, there was stringy growth at least $1.0 \mathrm{~cm}$ below the surface, and some gas formation was evident. With alkaline pyrogallol to achieve anaerobiosis, there was no visible growth in gelatin after 10 days and no digestion of milk. In glucose broth, there was heavy turbidity, much gas, and strong acidity. It was assumed that volatile acids were not formed because the broth had no odor. No motility was detected.

In 1911, Choukévitch (3) reported the isolation, from the large intestine of a horse, of an organism that closely resembled $B$. clostridie- formis (sic) in all of the main characteristics given in Ankersmit's description except that cells were motile in young cultures. Choukévitch stated that, after the cultures were more than $24 \mathrm{~h}$ old, the organism lost its motility because of the acid produced. He concluded that his isolate from the horse was a variant of $B$. clostridiiforme Ankersmit.

After the generic name Bacterium was rejected by the International Committee on Nomenclature of Bacteria (9), strains conforming to the original descriptions of $B$. clostridiiforme have led a peripatetic taxonomic existence. The various names under which these strains have been described and studied have been well documented by Holdeman and Moore (6). Until 1973 , names that had been accepted as validly published and legitimate (2) were Eggerthella clostridiiformis (Burri and Ankersmit) Beerens, Castel, and Fievez (H. Beerens, M. M. Castel, and L. Fievez, International Congress for Microbiology, Montreal, 1962, Abstr. 120) for the nonmotile strains and Fusocillus girans Prévot (14) and Fusobacterium girans (Prévot) Macdonald (J. B. Macdonald, Ph.D. thesis, Univ. of Toronto, Toronto, Canada, 1953) for the motile strains. In 1973 , the International Subcommittee on Taxonomy of the Anaerobic, Gram-Negative Rods recommended that all anaerobic, gram-negative, nonmotile or peritri- 
chous, nonsporeforming rods that did not produce butyric acid from the fermentation of carbohydrate be placed in the genus Bacteroides. Because these organisms produced formic, acetic, and sometimes traces of lactic and succinic acids, as well as ethanol (5), the nonmotile strains were named Bacteroides clostridiiformis subsp. clostridiiformis (Burri and Ankersmit) Holdeman and Moore and the motile variants were named Bacteroides clostridiiformis subsp. girans (Prévot) Holdeman and Moore (12).

All of these classifications were based on the assumption that the organisms were nonsporing, gram-negative rods. However, in 1967 Reinhold et al. reported (18) that, in their individual laboratories, a labeled strain of Eggerthella clostridiiformis (syn.: Ristella clostridiiformis) (Prévot $171 \mathrm{I}$, Beerens and Tahon 22) did form spores and was gram positive and motile in young (3- to 4-h-old) cultures. At this time, many strains with the general characteristics of $B$. clostridiiformis were being isolated in our laboratory from normal human fecal flora (13), and many that had been isolated from clinical specimens were being submitted to us for identification (11). These strains differed principally in motility, Gram reaction, and spore formation. It became important to determine whether these were not, in reality, all members of the same species of Clostridium. We have, therefore, reexamined 25 strains received from the Pasteur Institute, Paris, selected because they resembled morphologically the organism originally described by Ankersmit (1) and resembled biochemically and metabolically those organisms on which later emended descriptions of $B$. clostridiiformis were based $(4,6,14-17)$.

\section{MATERIALS AND METHODS}

Bacterial strains. The 25 strains studied, their sources where known, and the names given to them are listed in Table 1. These strains were identified in the laboratory of A.-R. Prévot at the Pasteur Institute, Paris. Sixteen of them were also studied extensively by M. Sebald (19) in the same Institute. Strain 3303 was kindly provided by H. Beerens, Pasteur Institute, Lille; the rest were supplied by Dr. Prévot. Two strains (0315 and 0316) were originally isolated from calf rumen by M. P. Bryant. We tested freeze-dried cultures sent by him as well as freeze-dried cultures of his isolates received from Dr. Prévot. Test results from both pairs of freezedried cultures were similar and have been combined.

Methods. The strains described in this report were characterized by methods and procedures described previously (7). Special attention was given to spores, heat resistance, motility, and flagella. Gram stains were made of young (2- to 3-h-old) cultures in media without carbohydrates to deter-

TABLE 1. Bacterial strains examined

\begin{tabular}{|c|c|c|c|c|c|c|}
\hline \multirow{3}{*}{$\begin{array}{l}\text { VPI } \\
\text { no. }\end{array}$} & \multirow{3}{*}{$\begin{array}{c}\begin{array}{c}\text { Pasteur Institute (Paris) no. } \\
\text { (source) }\end{array} \\
171 \mathrm{I}\end{array}$} & \multicolumn{3}{|c|}{ Previous identifications } & \multirow{2}{*}{\multicolumn{2}{|c|}{$\% G+C$}} \\
\hline & & \multirow{2}{*}{$\frac{\text { Prévot }^{a}}{\text { Ristella clostridiiformis }^{c}}$} & \multirow{2}{*}{$\frac{\text { Sebald }^{b}}{\text { iformis biacutus }}$} & \multirow{2}{*}{$\frac{\mathrm{VPI}}{\text { Clustridium } \mathrm{sp} .}$} & & \\
\hline & & & & & $48^{d}$ & $53^{e}$ \\
\hline 0292 & 2071 (pleural fluid) & Ristella biacuta & Fusiformis biacutus & Clostridium sp. & & 49 \\
\hline 0293 & $2760 \mathrm{~A}$ (throat) & Ristella biacuta & & Clostridium sp. & & \\
\hline 0294 & 2894 & Ristella biacuta & & Clostridium sp. & & \\
\hline 0304 & $141 \mathrm{D}$ & Spbaerophorus polymorpbus & Husiformis polymorphus & Bacteroides sp. & 47 & 47 \\
\hline 0315 & B58 (calf rumen) & Ristella biacuta & Fusiformis biacutus & $\begin{array}{l}\text { B. clostridiiformis } \\
\text { subsp. clostridiiformis }\end{array}$ & & 55 \\
\hline 0316 & T90 (calf rumen) & Ristella biacuta & Fusiformis biacutus & $\begin{array}{l}\text { B. clostridiiformis } \\
\text { subsp. clostridiformis }\end{array}$ & 48 & 53 \\
\hline 0432 & $85 \mathrm{II}$ & Ristella clostridiiformis & Fusiformis biacutus & Bacteroides sp. & & \\
\hline 0561 & $219 \mathrm{~B}$ & Zuberella clostridiiformis & Fusocillus girans & Bacteroides biacutus & & 50 \\
\hline 0562 & 2150 (blood) & Zuberella clostridiformis & Fusocillus girans & Clostridium sphenoides & & 46 \\
\hline 4041 & 2013 & Fusocillus girans & Fusocillus girans & Clostridium spbenoides & & 42 \\
\hline 4042 & $215 \mathrm{~B}$ & Fusocillus girans & Fusocillus girans & Clostridium sp. & & 50 \\
\hline 4043 & $1611 \mathrm{~B}$ (abscess, appendicitis) & Fusocillus girans & Fusiformis biacutus & Clostridium sp. & & 46 \\
\hline 4052 & 3484 (gangrenous appendix) & Fusocillus girans & & Clostridium sp. & & \\
\hline 4068 & 13211 & Ristella clostridiiformis & Fusocillus biacutus & Bacteroides biacutus & 48 & $40-4$ \\
\hline 4069 & 3219 (cervical cancer) & Ristella clostridiiformis & & Bacteroides biacutus & & \\
\hline 4139 & Potvin & Zuberella clostridiiformis & & Clostridium sp. & & \\
\hline 4348 & $63-0$ & fusocillus girans & Fusocillus girans & $\begin{array}{l}\text { B. clostridiiformis } \\
\text { subsp. clostridiformis }\end{array}$ & & 46 \\
\hline 4349 & 627 (throat culture) & Fusocillus girans & Fusocillus girans & Clostridium $\mathrm{sp}$ & & 46 \\
\hline 4867 & 3578B (liver abscess) & Ristella biacuta & & Bacteroides sp. & & \\
\hline 4870 & 4309 (abdominal abscess) & Ristella biacuta & & Clostridium sp. & & \\
\hline 4971 & 2972 & Ristella biacuta & & Clostridium sp. & & \\
\hline 5097 & $118-\mathrm{III}$ & Ristella biacuta & Fusiformis biacutus & Clostridium sp. & & $51-52$ \\
\hline 5115 & $3206 \mathrm{~B}$ & liusiformis nucleatus & & $\begin{array}{l}\text { B. clostriditormis } \\
\text { subsp. clostridiiformis }\end{array}$ & & \\
\hline 5121 & 201-III & Ristella biacuta & Fusiformis biacutus & Clostridium sp. & & 47 \\
\hline
\end{tabular}

"Prévot (18); ${ }^{b}$ Sebald (21); clater identified as Clostridium microsporum by Reinhold et al (20); "Determined by Johnson by thermal melting point $\left(\mathrm{T}_{\mathrm{m}}\right) ;{ }^{e}$ Deternined by Sebald by chromatographic analysis (21). 
mine whether gram-positive cells were present. Cultures on chopped-meat slants incubated for 2 weeks at $30 \mathrm{C}$, as well as cultures showing swellings in Gram stains from any broth or plate, were inoculated into PY broth (7) with $0.5 \%$ starch and $1.0 \%$ glucose added. This inoculated broth was then heated for $10 \mathrm{~min}$ at $80 \mathrm{C}$ and incubated at $37 \mathrm{C}$ to detect heat-resistant cells. Tests for motility were made from 2- to 3-h-old chopped-meat broth cultures and from the water of syneresis in peptone-yeast extract-glucose agar slants. Flagella stains were prepared as described previously (7). Production of $\mathrm{H}_{2} \mathrm{~S}$ was determined in prereduced SIM medium (BBL). Hydrogen gas production was determined by a method described previously (13).

The guanine plus cytosine $(G+C)$ content of the deoxyribonucleic acid (DNA) preparations was determined by J. L. Johnson (8), using the thermal melting point $\left(T_{m}\right)$ method (10), with an automatic recording spectrophotometer. DNA from Escherichia coli $\mathrm{B}$ was included in each set of analyses as a standard.

\section{RESULTS AND DISCUSSION}

All 25 strains studied conformed in morphology to the original and later descriptions of Bacteroides clostridiiformis: spindle shaped with pointed ends, occurring most often in pairs but also singly and sometimes in short chains (Fig. 1). The cells may stain irregularly with central or subterminal swellings. Cells are 0.3 to $0.9 \mu \mathrm{m}$ wide by 1.4 to $9.0 \mu \mathrm{m}$ long; usually they measure 0.3 to 0.5 by 2.0 to $5.0 \mu \mathrm{m}$. A comparison of the characteristics of this organism given in early descriptions (14-18) with the test results obtained on the 25 strains studied here is presented in Table 2. Those characteristics in which the 25 strains differ from the earlier descriptions are discussed below.

Spore formation. Spores were not found in any of 25 strains when they were first isolated, although it was reported that swellings or "spheroids" were observed in some (14). The organisms did not survive heating for $15 \mathrm{~min}$ at $80 \mathrm{C}$, although some resisted heating $5 \mathrm{~min}$ at $80 \mathrm{C}$ (14). Oval, subterminal spores (Fig. 2) that survive and produce outgrowth after heating for $10 \mathrm{~min}$ at $80 \mathrm{C}$ have now been found in all strains. The most dependable medium for inducing spore formation was a chopped-meat agar slant incubated for 2 weeks at $30 \mathrm{C}$, although in some cases heat-resistant spores could only be found on blood agar plates, in 3week-old chopped-meat broth cultures, or in a low-carbohydrate rumen fluid broth medium ( $E$ medium, 7).

All of the strains studied had been revived from at least two serially freeze-dried cultures. When we first examined these strains (between 1964 and 1968), spores were found in only 15 of the 25 strains. For the present study, we did

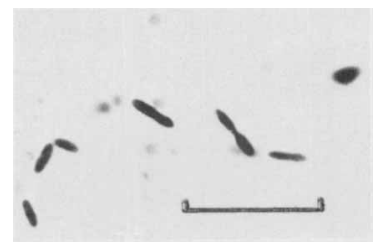

FIG. 1. Light micrograph of C. clostridiiforme ATCC 29084 (24-h-old culture in peptone-yeast extract broth). Bar $=10 \mu \mathrm{m}$.

make a more careful search for spores, but it may also be true that freeze-drying of this species selects for spore formation. Many other strains had been isolated in our laboratory from normal human feces and from clinical specimens and identified as $B$. clostridiiformis. Initially, we did not detect spores, and cells were not heat resistant. However, when 15 of these strains were revived from freeze-dried cultures, all were heat resistant, although we observed spores in only 9 strains.

Motility. Although Choukévitch (3) had originally proposed that the motile strains that were otherwise morphologically and biochemically similar to $B$. clostridiiformis be considered variants of that species, they were placed in different genera by later workers $(4,16,19)$ and in different subspecies by recent workers (12). Of the 25 strains studied here, 9 were presumably originally motile with a spinning motion, since they had been placed in the genus Zuberella or Fusocillus (Table 1). Flagella could not then be demonstrated $(14,16)$. In the present study, both motility and flagella were demonstrated in 12 strains. One strain was motile but flagella were not seen. Flagella were observed in stains of five strains in which no motile cells were observed. In seven strains, neither motility nor flagella was apparent. When flagella were seen, the cells were peritrichous or had a subpolar tuft of one to three flagella (Fig. 3). Meticulous care in staining and diligent search were required to verify the presence of flagella. Therefore, the usual laboratory tests would show motility to be a variable characteristic.

Gram reaction. Cells from 18- to 24-h-old cultures of the strains studied were consistently gram negative. However, this in no way precludes their membership in the genus Clostridium, which includes anaerobic rods that form heat-resistant spores and that are "generally Gram-positive, at least in the early stages of growth" (20). We have seen gram-positive cells in young (2- to 4-h-old) cultures of eight of these strains growing in non-carbohydrate media.

Colonies. Colonies in rumen fluid-glucose- 
TABLE 2. Characteristics of C. clostridiiforme (Burri and Ankersmit) comb, nov. and of species previously described ${ }^{a}$

\begin{tabular}{|c|c|c|c|c|c|c|c|}
\hline \multirow{2}{*}{$\begin{array}{c}\text { Reaction } \\
\text { or } \\
\text { characteristic }\end{array}$} & \multirow{2}{*}{ 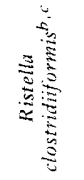 } & \multirow{2}{*}{ 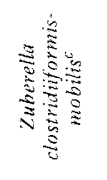 } & \multirow{2}{*}{ 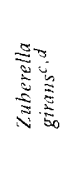 } & \multirow{2}{*}{ 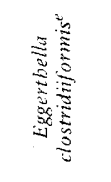 } & \multicolumn{3}{|c|}{ Clostridium clostriditforme } \\
\hline & & & & & 25 strains & $\%+$ & $\triangle \mathrm{TCC} 29084$ \\
\hline Spores & - & - & $\cdots$ & + & + & 100 & + \\
\hline Motility or flagellit & - & $+($ young $)$ & + & + & +- & 68 & + \\
\hline Gram reaction & - & - & - & + (young) & -+ & 32 & + (young) \\
\hline Gelatin digestion & - & - & - & & - & 0 & - \\
\hline Milk & - & & c & $-c$ & $\mathrm{v}$ & 44 & c \\
\hline Gas-Gilucose agar deep & + & + & + & + & 4,2 & 100 & 4 \\
\hline \multicolumn{8}{|l|}{ Acid from } \\
\hline Aratsinose & + & + & + & + & $-w$ & 32 & $w$ \\
\hline Cellobiose & . & . & . & + & $v$ & 56 & - \\
\hline Dulcitol & - & . & . & . & - & 0 & - \\
\hline Fructose & + & + & + & + & $+w$ & 100 & + \\
\hline Galactose & + & + & + & + & $\mathbf{w +}$ & 100 & $w$ \\
\hline Glucose & + & + & + & + & $+w$ & 100 & + \\
\hline Glycerol & & . & & . & - & 0 & - \\
\hline Inulin & - & . & - & & - & 0 & \\
\hline Lactose & $-(2 / 3)$ & . & + & + & $v$ & 60 & + \\
\hline Maltose & + & + & + & + & $+w$ & 100 & + \\
\hline Mannitol & . & & & - & - & 0 & - \\
\hline Salicin & . & . & . & + & $v$ & 52 & + \\
\hline Starch & - & . & - & . & $-w$ & 8 & - \\
\hline Sucrose & + & + & $+(3 / 5)$ & + & $+w$ & 100 & + \\
\hline Trchalose & . & . & - & + & $v$ & 48 & + \\
\hline Xylose & . & . & & + & $+w$ & 96 & + \\
\hline Neutral red reduction & + & + & + & . & + & 100 & + \\
\hline $\mathrm{NO}_{3}$ reduction & - & - & - & -- & $w-$ & 80 & w \\
\hline Indole & + & . & & . & $v$ & 50 & - \\
\hline $\mathrm{AMC}$ & +- & . & + & . & +- & 88 & + \\
\hline $\mathrm{H}_{2} \mathrm{~S}$ & $\ldots$ & . & - & $v$ & +- & 76 & + \\
\hline $\mathrm{NH}_{3}$ & + & + & + & . & + & 84 & + \\
\hline Threonine $\rightarrow$ propionate & : . & · & . & - & - & 0 & - \\
\hline Products from glucose & FAL2 & $A F_{2}$ & $\mathrm{AF} 2$ & $\mathrm{~F} \Lambda$ & $\Lambda F(\operatorname{ls} 2)$ & & Alils 2 \\
\hline
\end{tabular}

'Symbols: -, negative reaction: ', not reported; +, positive reaction + (carbohydrate cultures), pH below $5.5 ; c$, curd; $v$, variable reaction: $w$, weak reaction or $\mathrm{pH}$ between 5.5 and 6 ; numbers (gas), amount estimated on " to $4+$ 'seale. Where two reactions are given (e.g., '+w'), the first was the more usual, the second was observed less frequently. Products: $A$, acetic acid; $F$, tormic acid; $L$, lactic acid; $\$$, succinic acid; 2 , ethanol. For (: clostritifforme, capital letters indicate 1 mey (or more) per $100 \mathrm{ml}$ of culture; small letters indicate less than 1 meg/100 $\mathrm{ml}$ of culture. Products in parentheses were not uniformly detected

"Keinhold, Barnes, and Beerens (20). Strain 171 1 (Prevot), 22 (Becrens). The authors proposed that this organism be named ciostrutiun micosporum. See discussion in text.

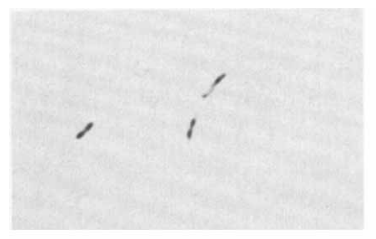

FIG. 2. Light micrograph of spore in cell of $C$. clostridiiforme ATCC 29084 (2-wk-old culture on chopped-meat slant). See Fig. 1 for scale.

cellobiose agar roll tubes after 2 days were pinpoint to $2 \mathrm{~mm}$ in diameter, circular, entire to slightly erose, lenticular, translucent to opaque, and gray-white with a mottled or mosaic appearance.

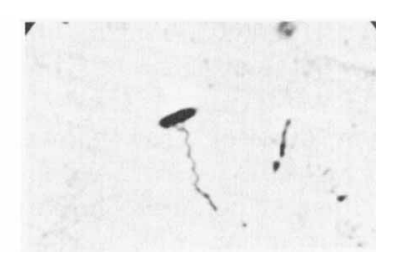

FIG. 3. Light micrograph of cells of C. clostridiiforme VPI 4069 stained for flagella by modification of Leifson method (7). See Fig. 1 for scale.

Surface colonies on blood agar plates incubated anaerobically for 2 days were 0.5 to 2.0 $\mathrm{mm}$ in diameter, entire to slightly scalloped or erose, convex to slightly peaked, translucent to opaque, gray-white, and usually had a mottled 
or mosaic appearance. No hemolytic activity was detected on sheep blood agar.

Cultural characteristics. Growth was vigorous in prereduced, anaerobically sterilized (PRAS) media without additional stimulants. There was no growth on plates incubated aerobically or in a candle jar. Broth cultures were turbid with a heavy, sometimes viscous or ropy, sediment in $24 \mathrm{~h}$. Temperature for optimal growth was $37 \mathrm{C}$, although some grew equally well at $30 \mathrm{C}$. There was moderate growth at $25 \mathrm{C}$ and usually poor growth at $45 \mathrm{C}$.

Biochemical reactions. Characteristics of the strains tested are listed in Tables 2 and 3 . No reaction that was variable among strains could be correlated with any other variable reaction. In many cases, these characteristics varied within a strain when the strain was tested several times.

Products of the fermentation of peptone-yeast extract-glucose were acetic acid $(0.7$ to $5.9 \mathrm{meq} /$ $100 \mathrm{ml})$, formic acid $(0.0$ to $2.1 \mathrm{meq} / 100 \mathrm{ml})$, and/or ethanol. Usually traces of succinic and lactic acids were also formed.

In addition, lactate was not converted to propionate, but pyruvate and gluconate were converted to acetate and usually formate and ethanol by all strains tested.

Urease was not formed by the five strains examined.

meso-Diaminopimelic acid was present in the cell walls of the 15 strains tested (C. S. Cummins, personal communication).

Pathogenicity. True toxin has not been found to be produced by these strains, but Prévot reported (15) that intravenous injections of $2 \mathrm{ml}$ of a 24-h-old culture into a rabbit, or intramuscular injections of the same inoculum into a guinea pig, first caused anorexia, then cachexia, then death in 11 to 15 days. At autopsy, no lesions were found, and the organism could not be isolated from the inoculation site or from the blood. He ascribed the reactions to generalized, nonspecific intoxication. We have found, in the 14 strains tested, that intraperitoneal injections of $0.5 \mathrm{ml}$ of supernatant fluids from 1- or 3-day-old chopped-meat-glucose cultures are not toxic to mice.

Taxonomic position. Reinhold et al. (18) had proposed that organisms with the rather distinctive morphology of that in the 12 strains they studied (gram-negative, straight rods with pointed ends, lancet shaped, appearing singly, in pairs, or in short chains) be transferred to the genus Clostridium, since they observed spores in all strains. They felt that these strains resembled most closely an organism described by Spray in 1948 and named Clostrid-

\begin{tabular}{lccc}
\multicolumn{4}{c}{ Table 3. Reactions of strains of $C$. clostridiiforme ${ }^{\mathrm{a}}$} \\
\hline $\begin{array}{l}\text { Substrate } \\
\text { or reaction }\end{array}$ & Test results & $\%+$ & ATCC \\
\hline Acid from & & & 29084 \\
\hline Adonitol & - & 0 & - \\
Amygdalin & - & 0 & - \\
Dextrin & - w & 12 & - \\
Erythritol & - & 0 & - \\
Glycogen & - & 0 & - \\
Inositol & - & 0 & - \\
Mannose & w+ & 100 & w \\
Melezitose & - w & 16 & - \\
Melibiose & - w & 40 & - \\
Raffinose & +- & 80 & + \\
Rhamnose & +- & 72 & + \\
Ribose & - & 0 & - \\
Sorbitol & - & 4 & - \\
Sorbose & - & 8 & - \\
Starch & - & 8 & - \\
Esculin hydrolysis & + & 92 & + \\
Starch hydrolysis & - & 0 & - \\
Hippurate hydrolysis & +- & 68 & + \\
H & - & 96 & + \\
Catalase & - & 0 & - \\
Lecithinase & - & 0 & - \\
Lipase & - & 0 & - \\
\hline
\end{tabular}

${ }^{a}$ See Table 2 for symbols.

ium microsporum (21). The organisms Reinhold et al. studied clearly belonged in two metabolic groups, one producing formic and acetic acids, and the other producing formic, butyric, and acetic acids from the fermentation of glucose. Characteristics reported by them for the group that includes the proposed neotype strain are similar to those listed above (Table 2). Since Spray's proposal of the name Clostridium microsporum, accompanied by a meager description of characteristics of one strain that has been lost, was made in 1948, the specific epithet attached to these organisms by Ankersmit in 1906 has priority.

We agree with Reinhold et al. (18) that the presence or absence of motility does not provide a sufficient reason for separation of these organisms into two species. Motility is variable and usually sluggish, and so we do not believe that even placing it in a subspecies is justified. Since heat-resistant cells have been found in the 25 strains studied, we propose that anaerobic, mainly gram-negative, spindle-shaped rods (with pointed ends) that are usually found in pairs, and are saccharolytic and nonproteolytic, and produce acetic and formic acids and/or ethanol, and usually large amounts of hydrogen gas, from the fermentation of carbohydrate be designated Clostridium clostridiiforme (Burri and Ankersmit) comb. nov. VPI 3303 (= 
Pasteur Institute $171 \mathrm{I}=$ Beerens 22) is here designated as the neotype strain of $C$. clostridiiforme. It has been deposited in the American Type Culture Collection (ATCC) under the number 29084 . The characteristics of this strain are listed in Tables 2 and 3.

$\mathrm{G}+\mathrm{C}$ content of the DNA. Four strains tested have a $\mathrm{G}+\mathrm{C}$ content of 47 to $48 \mathrm{~mol} \%$ by $T_{m}$. The $\mathrm{G}+\mathrm{C}$ content of the neotype strain is 48 mol\%. Sebald (19) reported that the $\mathrm{G}+\mathrm{C}$ content of 16 of the strains ranged from 40 to 53 mol\%, as determined by chromatographic analysis (Table 1). We cannot be certain that the strains she studied were the same as those we worked with, but her strains bore the same Pasteur Institute numbers as the strains we studied.

Sources. C. clostridiiforme is a component of the normal intestinal tracts of birds, humans, and other animals. It has been isolated from human and other animal infections, from abdominal, cervical, scrotal, and pleural abscesses, and from septicemias, peritonitis, and appendicitis.

Distinguishing characteristics. When spores are not detected in this species, it can be distinguished from other gram-negative organisms by its fermentation products: butyric acid is not formed as in Fusobacterium or Butyrivibrio; only trace amounts of succinic acid are formed, unlike the large amounts formed by many Bacteroides species or by Succinivibrio or Succinimonas species; lactic acid is not the only major product as in Leptotrichia; and, unlike Selenomonas species, propionic acid is not formed.

C. clostridiiforme differs from other clostridia principally in morphology: the spindleshaped, mainly gram-negative cells are rather distinctive. It differs from other clostridia that do not hydrolyze gelatin and that produce acetic and formic acids and ethanol from glucose (7) by the following characteristics: $C$. indolis ( $\mathrm{mol} \% \mathrm{G}+\mathrm{C}=44$ ) has terminal spores, does not produce acid from mannose, and hydrolyzes starch; C. sphenoides $(\mathrm{mol} \% \mathrm{G}+\mathrm{C}=41)$ produces acid from mannitol; and C. ramosum ( $\mathrm{mol} \% \mathrm{G}+\mathrm{C}=26$ to 28 ) makes little if any gas and produces acid from amygdalin, esculin, and mannitol.

\section{ACKNOWLEDGMENTS}

We are grateful to John L. Johnson for determining the $\mathrm{G}+\mathrm{C}$ ratios, to C. $\mathrm{S}$. Cummins for analysis of cell wall components, and to W. E. C. Moore and Lillian V. Holdeman for helpful discussion and criticism.

This investigation was supported by Public Health Service grant 14604 from the National Institute of General Medical Sciences.

\section{REPRINT REQUESTS}

Address reprint requests to: Elizabeth P. Cato, V.P.I. Anaerobe Laboratory, P.O. Box 49, Blacksburg, Va. 24060.

\section{LITERATURE CITED}

1. Ankersmit, P. 1906. Untersuchungen über die Bakterien im Verdauungskanal des Rindes. Zentralbl. Bakteriol. Parasitenkd. Infektionskr. Hyg. Abt. 1 Orig. 40:100-118.

2. Buchanan, R. E., J. G. Holt, and E. F. Lessel, Jr. (ed.). 1966. Index Bergeyana. The Williams and Wilkins Co., Baltimore.

3. Choukévitch, J. 1911. Etude de la flore bactérienne du gros intestin du cheval. Ann. Inst. Pasteur Paris 25:345-367.

4. Hauduroy, P., G. Ehringer, G. Guillot, J. Magrou, A.R. Prévot, Rosset, and A. Urbain. 1953. Dictionnaire des bactéries pathogènes, 2nd ed. Masson and Co., Paris.

5. Holdeman, L. V., and W. E. C. Moore (ed.). 1970. Outline of clinical methods in anaerobic bacteriology, 2nd rev., p. 33. Virginia Polytechnic Institute Anaerobe Laboratory, Blacksburg.

6. Holdeman, L. V., and W. E. C. Moore. 1974. Genus I. Bacteroides Castellani and Chalmers 1919, p. 385404. In R. E. Buchanan and N. E. Gibbons (ed.), Bergey's manual of determinative bacteriology, 8th ed. The Williams and Wilkins Co., Baltimore.

7. Holdeman, L. V., and W. E. C. Moore. (ed.) 1975. Anaerobe laboratory manual, 3rd ed. Virginia Polytechnic Institute and State University, Blacksburg.

8. Johnson, J. L., and B. S. Francis. 1975. Taxonomy of the clostridia: ribosomal ribonucleic acid homologies among the species. J. Gen. Microbiol. 88:229-244.

9. Judicial Commission, International Commission on Bacteriological Nomenclature. 1954. Int. Bull. Bacteriol. Nomen. Taxon. 4:142.

10. Marmur, J., and P. Doty. 1962. Determination of the base composition of deoxyribonucleic acid from its thermal denaturation temperature. J. Mol. Biol. 15:109-118.

11. Moore, W. E. C., E. P. Cato, and L. V. Holdeman. 1969. Anaerobic bacteria of the gastrointestinal flora and their occurrence in clinical infection. J. Infect. Dis. 119:641-649.

12. Moore, W. E. C., and L. V. Holdeman. 1973. New names and combinations in the genera Bacteroides Castellani and Chalmers, Fusobacterium Knorr, Eubacterium Prévot, Propionibacterium Delwiche, and Lactobacillus Orla-Jensen. Int. J. Syst. Bacteriol. 23:69-74.

13. Moore, W. E. C., and L. V. Holdeman. 1974. Human fecal flora: the normal flora of 20 Japanese-Hawaiians. Appl. Microbiol. 27:961-979.

14. Prévot, A.-R. 1940. Recherches sur la flore anaérobie de l'intestin humain: Fusocillus girans nov. sp. C.R. Soc. Biol. 133:246-248.

15. Prévot, A.-R. 1940. Recherches sur la flore anaérobie de l'intestin humain. Caractères culturaux, pathogéniques et biochimiques de Ristella clostridiiformis (Burri et Ankersmit), P. 1938. C.R. Soc. Biol. 133:384-386.

16. Prévot, A.-R. 1957. Manuel de classification et de determination des bactéries anaérobies, 3rd ed. Masson and Co., Paris.

17. Prévot, A.-R., A. Turpin, and P. Kaiser. 1967. Les bactéries anaérobies. Dunod, Paris.

18. Reinhold, L., E. M. Barnes, and H. Beerens. 1967. Identification de Ristella biacutus (Prévot 1967) (ex Fusiformis biacutus Prévot) avec Clostridium micro- 
sporum (Spray 1947). Bull. Off. Int. Epiz. 67:1-7.

19. Sebald, M. 1962. Etudes sur les bactéries anaérobies gram-négatives asporulees. Imprimerie Barneoud S. A. Laval, France.

20. Smith, L. DS., and G. Hobbs. 1974. Genus II. Clostridium Prazmowski 1880, p. 551. In R. E. Buchanan and
N. E. Gibbons (ed.), Bergey's manual of determinative bacteriology, 8th ed. Williams and Wilkins, Baltimore.

21. Spray, R. S. 1948. Three new species of the genus Clostridium. J. Bacteriol. 55:839-842.

\section{EDITOR'S NOTE}

The paper by Kaneuchi et al. (p. 195-204 of this issue) on Bacteroides clostridiiformis was submitted for publication prior to the submission by Cato and Salmon. The papers were assigned by the Publications Office to different members of the IJSB Editorial Panel, and both papers were independently found acceptable for publication. Since the later paper not only confirms the transfer of Bacteroides clostridiiformis to Clostridium, as proposed by Kaneuchi et al., but also contains additional supporting evidence for this transfer, both papers have been published in this issue of the IJSB. It should be noted that since the paper by Kaneuchi et al. has priority, these individuals, and not Cato and Salmon, are to be cited as the authors of the new combination Clostridium clostridiiforme. Furthermore, the strain proposed by Kaneuchi et al. as the neotype for C. clostridiiforme has priority over that proposed by Cato and Salmon. 